\title{
New Conglomerates and the Ecosystem Advantage
}

\author{
Nigel Walton \\ University of Worcester, Worcester, United Kingdom
}

\begin{abstract}
It is the purpose of this paper to explore the emergence of a new form of web-based company and how the new organisational form is able to access multiple-markets and industries by exploiting the benefits of a platform ecosystem business model. Internet-based companies such as Amazon, Google, Facebook, and Apple were referred to as the "Gang of Four" in May, 2011, by Eric Schmidt, Executive Chairman of Google. These 21st century companies are leading an internet-based consumer revolution which is having a disruptive impact on a broad range of industries and markets. Using their platform-based ecosystems, the internet-based corporations are able to leverage these core competencies and enter industries that appear unrelated to their core businesses. This has given rise to a new form of conglomerate business model that contrasts with the Western industrial conglomerates of the 1960s and early 1970s. Most of these corporations were broken-up in the early 1980s and the remaining core businesses resorted to focused strategies. The paper also analyses why the new internet-based firms do not follow the positioning school of strategy and seek monopolistic rents - profits arising from market power-by locating in attractive industries. Instead, these firms leverage core competencies and achieve Ricardian economic rents-profits arising from superior resources - through strategies of stretch and leverage. By adopting a core competency tree configuration, a core competency platform is leveraged which allows the internet-based firms to enter multiple markets using asset-light business models. This new form of competitive advantage is based on having a superior ecosystem that uses data as the key resource instead of capital; capital being the main resource underpinns the success of the traditional Western conglomerates of the 1960s and early 1970s.
\end{abstract}

Keywords: ecosystem, internet, platform, conglomerate, core competency, industry structure

\section{Introduction}

This paper will analyse the development of the web-based companies and how they have evolved into a new form of conglomerate business. This type of business is contrasted with the traditional Western conglomerates of the 1960s and 1970s. In the traditional conglomerate companies, there were very few synergies and value destruction was commonplace. Most of the diversified industrial firms were taken over during the private equity era and the non-core assets sold off to create new focused companies positioned in industries with clearly definable boundaries and standard industrial classifications (SIC codes). However, following the evolution of the internet, a new type of firm with a platform ecosystem as its base (Gawer, 2009), emerged that could achieve the diversity of its Western predecessors using asset light core competency based strategies, for example, firms such as Amazon, Google, Apple, and Facebook have caused disruption in a range

Nigel Walton, senior lecturer, MBA., Dip. M., (BA (Hons), Worcester Business School, University of Worcester, Worcester, United Kingdom.

Correspondence concerning this article should be addressed to Nigel Walton, University of Worcester, City Campus, Castle Street, Worcester, WR1 3AS, United Kingdom. E-mail: N.Walton@worc.ac.uk. 
of industries that are non-core to their established businesses. Although Apple is strong in devices (originally computers), Google is strong in search, Amazon is strong in e-commerce, and Facebook is strong in social networking, these companies are now entering or influencing a broad range of markets and industries beyond their core businesses. These include publishing, media, home entertainment, computing (software and hardware), advertising/marketing, telecommunications, and bricks-and-mortar retail operations. These companies, by virtue of their business models, are data-rich and can utilise big data to identify, target, and serve a broad range of customers in multiple markets.

This paper will analyse how the internet-based companies are able to develop an ecosystem advantage over traditional companies. This ecosystem advantage incorporates multiple-business models that achieve high Ricardian rents (Grant, 2008) through the leveraging of core competencies across industries as opposed to positioning themselves within separate industries. The impact of the new internet-firms has been likened to creative destruction (Schumpeter, 1942) where significant disruptions are occurring and new business models are emerging. The inability of traditional incumbent firms to respond to the threat of the new conglomerates will also be considered.

\section{Literature Review}

Although conglomerate companies are still commonplace in emerging markets such as India and South Korea, these company structures were largely dismantled in the West during the 1980s (Davis, Diekmann, \& Tinsley, 1994; Johnston, 2000) as a result of aggressive mergers and acquisitions strategies by the private equity firms (Slater, 1999; Sobel, 1999). Once the target firms had been acquired, they were then broken-up and repositioned within specific industries adopting focused strategies.

These developments all pre-dated the birth of the worldwide web in 1992 and the rapid growth of a new type of internet-based company. These new conglomerates are the result of the evolution of the internet as a commercial ecosystem spanning several decades. Table 1 documents the life cycle of the internet as an ecosystem from the earliest personal computers to the present day.

Table 1

New Internet-based Technology Ecosystem

\begin{tabular}{|c|c|c|}
\hline Foundation Stage (1976-1991) & Growth Stage 1 (1992-2000) & Growth Stage 2 (2000-2013) \\
\hline Key Technologies & Key Technologies & Key Technologies \\
\hline $\begin{array}{l}\text { - Microprocessor } \\
\text { - MS Dos/Killer Apps } \\
\text { - Intel } 486 \text { \& Pentium Chips }\end{array}$ & $\begin{array}{l}\text { - World Wide Web } \\
\text { - Digitisation } \\
\text { - Fibre Optic Cable } \\
\text { - Encryption }\end{array}$ & $\begin{array}{l}\text { - Linux } \\
\text { - 3G Smartphones, iPods, iPads, E-readers } \\
\text { - Phone Apps } \\
\text { - Big Data } \\
\text { - 4G Networks }\end{array}$ \\
\hline Key Developments & Key Developments & Key Developments \\
\hline $\begin{array}{l}\text { - Birth of the PC Industry } \\
\text { - 1977: Apple 1-2 } \\
\text { - IBM: Open Architecture (the Clones) } \\
\text { - Industry Standard (WINTEL) }\end{array}$ & $\begin{array}{l}\text { - Global Village } \\
\text { - E-commerce } \\
\text { - Dot Com Boom } \\
\text { - Early Search Engines }\end{array}$ & $\begin{array}{l}\text { - Web 2.0 } \\
\text { - Digital Downloads and Streaming } \\
\text { - Open Source Software } \\
\text { - Cloud Computing } \\
\text { - M-commerce }\end{array}$ \\
\hline
\end{tabular}

Source: Adapted from Walton (2012).

During the early years of personal computers (PCs) and the evolution of the internet, there were four firms (Intel, Microsoft, Cisco, and Dell) that played a prominent role in developing the worldwide web as platform ecosystem. These were Intel and Microsoft, who established the industry standard for PCs. Without the 
industry standard, Tim Berners-Lee wouldn't have had a globally compatible platform upon which to base the worldwide web. Cisco was instrumental in providing all the network equipment required for the new Internet platform (Gawer \& Cusumano, 2002). Dell also played a key role in making PCs affordable to the mass public through their low cost and low price direct sales model. Finally, these four companies are still highly successful today but they have now been overtaken by a new form of consumer web-based company and a new "Gang of Four". This transition is depicted in the punctuated equilibrium model in Figure 1.

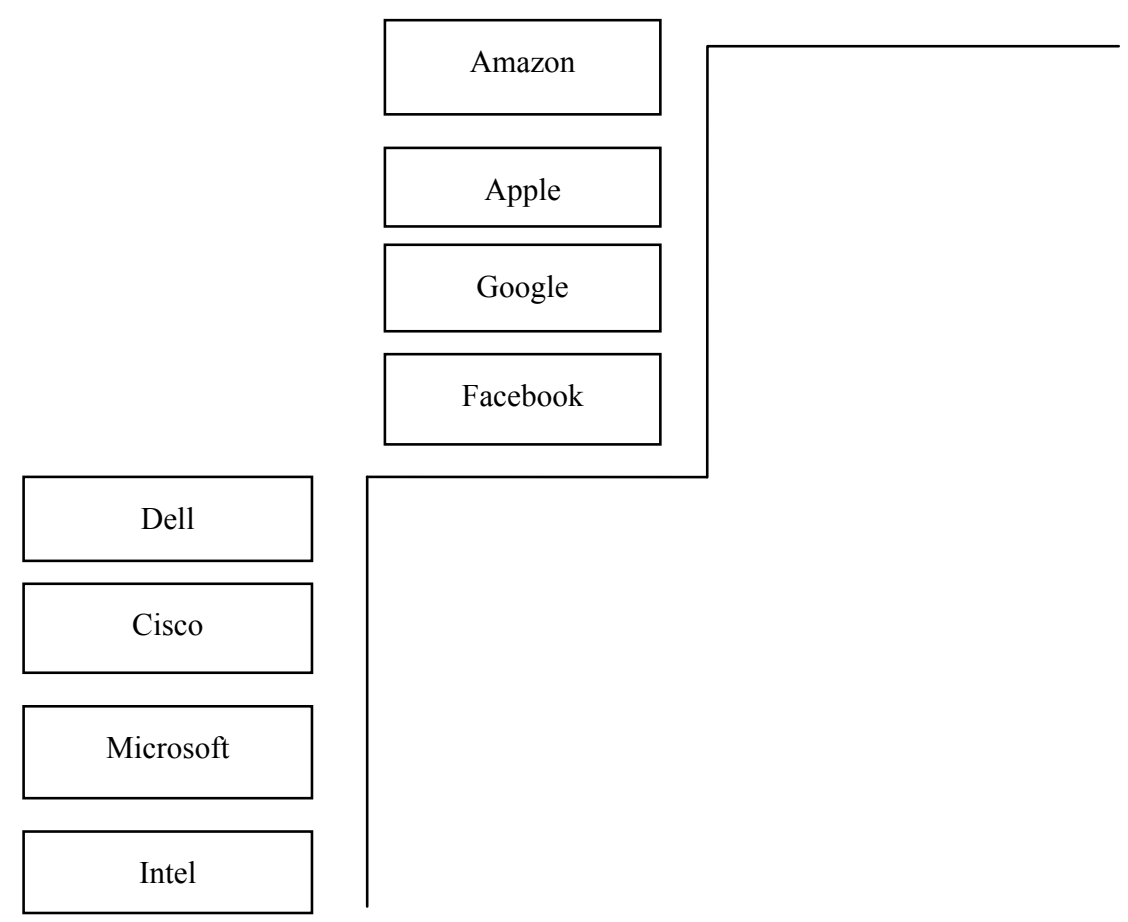

Figure 1. Punctuated equilibrium model. Source: Eldredge and Gould (1972).

The huge economic rents appropriated by the "Gang of Four" are reflected in a combined market capitalization value of nearly one trillion US dollars (\$907 billion). If the market capitalisation of Microsoft is added, the total value reaches US\$1.2 trillion. Microsoft has been forced to adopt an aggressive internet strategy due to the arrival of downloadable open source software resulting in a move into cloud computing. The new "Big Five" internet-based technology firms now represent a large platform ecosystem consisting of three layers. Using an adaptation of the model - pathway's of influence in a technology ecosystem (Adomavicius, Bockstedt, Gupta, \& Kauffman, 2008), the full platform ecosystem of the "Big Five" technology firms is illustrated in Table 2.

The three layers consist of hardware and software, content and services. The table illustrates the areas that each company is targeting. Apple, Microsoft, and Google seek to occupy all areas of the ecosystem and this is why they are categorized under the heading primary platform layer. Apple has mastered hardware and software integration along with content availability although its services are in need of improvement. Microsoft remains the dominant PC platform and has made inroads with its services (while its content needs to be bolstered). Google has become a leader in mobile with Android. It also has the best services and has recently begun focusing on growing its content repository with music streaming. 
Table 2

Pathway's Influence in a Technology Ecosystem Model

\begin{tabular}{|c|c|c|c|c|c|c|}
\hline & \multicolumn{3}{|c|}{ Primary Platform Layer } & \multicolumn{2}{|c|}{ Secondary Platform Layer } \\
\hline & & Apple & Microsoft & Google & Facebook & Amazon \\
\hline \multirow{5}{*}{$\begin{array}{l}\text { Hardware \& } \\
\text { Software }\end{array}$} & PC Operating System & OS X & Windows & Chrome OS & \begin{tabular}{|l|} 
3rd Party \\
Integration (OS X \& \\
Windows 8) \\
\end{tabular} & \\
\hline & $\begin{array}{l}\text { Mobile Operating } \\
\text { System }\end{array}$ & iOS & Windows Phone & Android & \begin{tabular}{|l|} 
3rd Party \\
Integration (iOS \& \\
Windows Phones) \\
\end{tabular} & $\begin{array}{l}\text { Android } \\
\text { Modified }\end{array}$ \\
\hline & \begin{tabular}{|l|} 
1st party Mobile \\
Hardware \\
\end{tabular} & iPhone \& iPad & Surface & Nexus & & Kindle Fire \\
\hline & Internet Browser & Safari & Internet Explorer & Chrome & & Silk \\
\hline & Productivity Software & iWork & Office & Google Apps & & \\
\hline \multirow{7}{*}{ Content } & $\begin{array}{l}\text { Mobile App } \\
\text { Distribution }\end{array}$ & App store & Windows Store & Google Play & $\begin{array}{l}\text { Facebook App } \\
\text { Center }\end{array}$ & $\begin{array}{l}\text { Amazon App } \\
\text { Store for } \\
\text { Android } \\
\end{array}$ \\
\hline & PC App Distribution & $\begin{array}{l}\text { Mac App } \\
\text { Store }\end{array}$ & Windows Store & $\begin{array}{l}\text { Chrome Web } \\
\text { Store }\end{array}$ & \begin{tabular}{|l} 
Facebook App \\
Center
\end{tabular} & \\
\hline & Music Sales & iTunes & $\begin{array}{l}\text { Xbox Music } \\
\text { Store }\end{array}$ & Google Play & & \begin{tabular}{|l|} 
Amazon MP3 \\
Music Store
\end{tabular} \\
\hline & Music Streaming & \begin{tabular}{|l|} 
iTunes in the \\
Cloud \& \\
iTunes Match \\
\end{tabular} & Xbox Music Pass & Google Music & & $\begin{array}{l}\text { Amazon Cloud } \\
\text { Player }\end{array}$ \\
\hline & Video & iTunes & Xbox Video & $\begin{array}{l}\text { Google Play/You } \\
\text { Tube }\end{array}$ & & \begin{tabular}{|l} 
Prime Instant \\
Video/Instant \\
Video Store \\
\end{tabular} \\
\hline & E-books & iBookstore & & Google Play & & Kindle Store \\
\hline & TV Platform & Apple TV & Xbox Live & Google TV & & $\begin{array}{l}\text { Prime Instant } \\
\text { Video }\end{array}$ \\
\hline \multirow{13}{*}{ Services } & Cloud Storage & iCloud & SkyDrive & Google Drive & $\begin{array}{l}\text { Photo Sync (Photo } \\
\text { Only) }\end{array}$ & Cloud Drive \\
\hline & E-Mail Service & iCloud & Outlook & G-mail & \begin{tabular}{|l|} 
Facebook \\
E-mail
\end{tabular} & \\
\hline & Social Networking & & Soci & Google+ & Facebook & \\
\hline & $\begin{array}{l}\text { Mobile Messaging } \\
\text { Service }\end{array}$ & iMessage & Skype & Google Voice & \begin{tabular}{|l|} 
Facebook \\
Messenger
\end{tabular} & \\
\hline & $\begin{array}{l}\text { Video Calling } \\
\text { Service }\end{array}$ & Facetime & Skype & Hangouts & $\begin{array}{l}\text { Facebook Video } \\
\text { Calling/ } \\
\text { Skype-based } \\
\end{array}$ & \\
\hline & Navigation Service & Apple Maps & Bing Maps & Google Maps & & \\
\hline & Online Advertising & iAd & \begin{tabular}{|l|} 
Bing Search \\
Advertising
\end{tabular} & AdWords & Sponsored Stories & \\
\hline & Search & & Bing & Google & Graph Search & \\
\hline & E-commerce & & Bing Shopping & Google Shopping & Facebook Gifts & Amazon.com \\
\hline & Brick \& Mortar retail & Apple Store & Microsoft Store & & & \\
\hline & Volce Interface & Siri & $\begin{array}{l}\text { Tellme \& Kinect } \\
\text { Voice Commands }\end{array}$ & Google Now & & $\begin{array}{l}\text { Yap-in } \\
\text { Development }\end{array}$ \\
\hline & Cloud Hosting & & Azure & & & \begin{tabular}{|l|} 
Amazon Web \\
Services
\end{tabular} \\
\hline & \begin{tabular}{|l|} 
Computing \\
Virtualisation
\end{tabular} & & Azure & $\begin{array}{l}\text { Google Compute } \\
\text { Engine }\end{array}$ & & \begin{tabular}{|l} 
Elastic Cloud \\
Compute
\end{tabular} \\
\hline
\end{tabular}

Source: Adapted from Adomavicius et al. (2008). 
Facebook is focusing heavily on the service element of the ecosystem with new social initiatives intending to connect people. Amazon is strongly focused on content and sells hardware at or near cost in order to expand distribution of its content. These two companies are therefore categorized under the secondary platform layer.

\section{Ecosystem Advantage vs. Cost \& Differentiation Advantage}

As firms in Western markets and industries underwent a period of restructuring from conglomerate to focused organizations, strategic thinking and analysis had become increasingly influenced by the positioning school and Porter's industrial organization economics perspective. According to Porter (1979), firms should locate or position themselves in an attractive industry (determined by the Five Forces model) and then establish a competitive advantage over their rivals based on a superior cost or differentiation advantage.

However, as the personal computer industry began its rapid growth during the $1980 \mathrm{~s}$, followed by the rapid diffusion of the internet in the 1990s (see Table 1 above), it became increasingly difficult to define industries in the traditional manner. Technology was effectively blurring and in some cases removing many industry boundaries. According to Moore (1996):

What we are seeing is the end of industry... The traditional industry boundaries that we've all taken for granted are blurring and in many cases crumbling... In place of industry, I suggest an alternative, more, appropriate term: business ecosystem... Business ecosystems span a variety of industries. The companies within them co-evolve capabilities around the innovation and competitively support new products, satisfy customer needs, and incorporate the next round of innovation. (p. 15)

This is a trend that has accelerated at a formidable pace with the development of m-commerce and mobile communications, for example, the original mobile phone was produced by one industry-telecommunications. However, a modern smart phone involves the inputs of at least four industries, namely: telecommunications (for voice calls and texts), computing (for e-mail and the Internet), media (for content), and consumer electronics (for video and photographs). In fact, no single industry or firm is capable of producing a smart phone. This now requires the input of a vast technology ecosystem involving a broad range of firms. Ecosystems operate differently to the traditional industries defined by Porter's Five Forces model (1979). Ecosystem firms do not create barriers to entry, seek monopolistic rents from high scale and high levels of bargaining power in the same way as traditional industrial corporations. Ecosystem firms add value to their ecosystem through symbiotic relationships and co-evolution. Moore (1996) defined a business ecosystem as:

An economic community is supported by a foundation of interacting organizations and individuals - the organisms of the business world. This economic community produces goods and services of value to customers, who are themselves members of the ecosystem. The member organizations also include suppliers, lead producers, competitors, and other stakeholders. Over time, they co-evolve their capabilities and roles, and tend to align themselves with the directions set by one or more central companies. Those companies holding leadership roles may change over time, but the function of ecosystem leader is valued by the community because it enables members to move toward shared visions to align their investments and to find mutually supportive roles. (p. 26)

The reference to leadership roles is very important. This is what Iansiti and Levien (2004) referred to as a keystone strategy. The keystone company adds value to the ecosystem by incentivising other firms to enter and help co-evolve new technologies, products, and services. This is evident in Table 2 where leadership roles are being pursued by each of the five firms in specialist elements of the three platform layers. This doesn't, however, eliminate the development of individual ecosystems which compete against one-another. 
Moore's definitions help to illustrate how the nature of competitive advantage has changed from a focus on cost and differentiation to shared value involving consumers as well as individual firms. In fact, in his article Strategy and the Internet, Porter (2001) commented on how the internet companies had commoditised many service industries and this had resulted in differentiation becoming irrelevant.

In the 1990s, a new school of strategy evolved known as the resource-based view (RBV). This approach focused on the internal core competencies of the firm. This perspective is more closely aligned to the ecosystem model and helps to explain some of the reasons for the superior performance of the new internet-based firms and their ability to succeed in multiple-markets. Prahalad and Hamel (1990) likened the diversified corporation to a large tree. They said that the roots of the tree were the core competencies (the collective learning in the organization), the trunk and the major limbs were the core products, the smaller branches were the business units and the leaves, flowers and fruit were the end products.

If this framework is adapted, it can be applied to the platform ecosystem model in Table 2. The hardware and software become the routes, the content becomes the trunk and major limbs, and the services become the smaller branches, leaves, flowers and fruit. The life blood of the new core competency tree is the profuse amount of data that it collects and this occurs at all levels. This concept is illustrated in Figure 2.

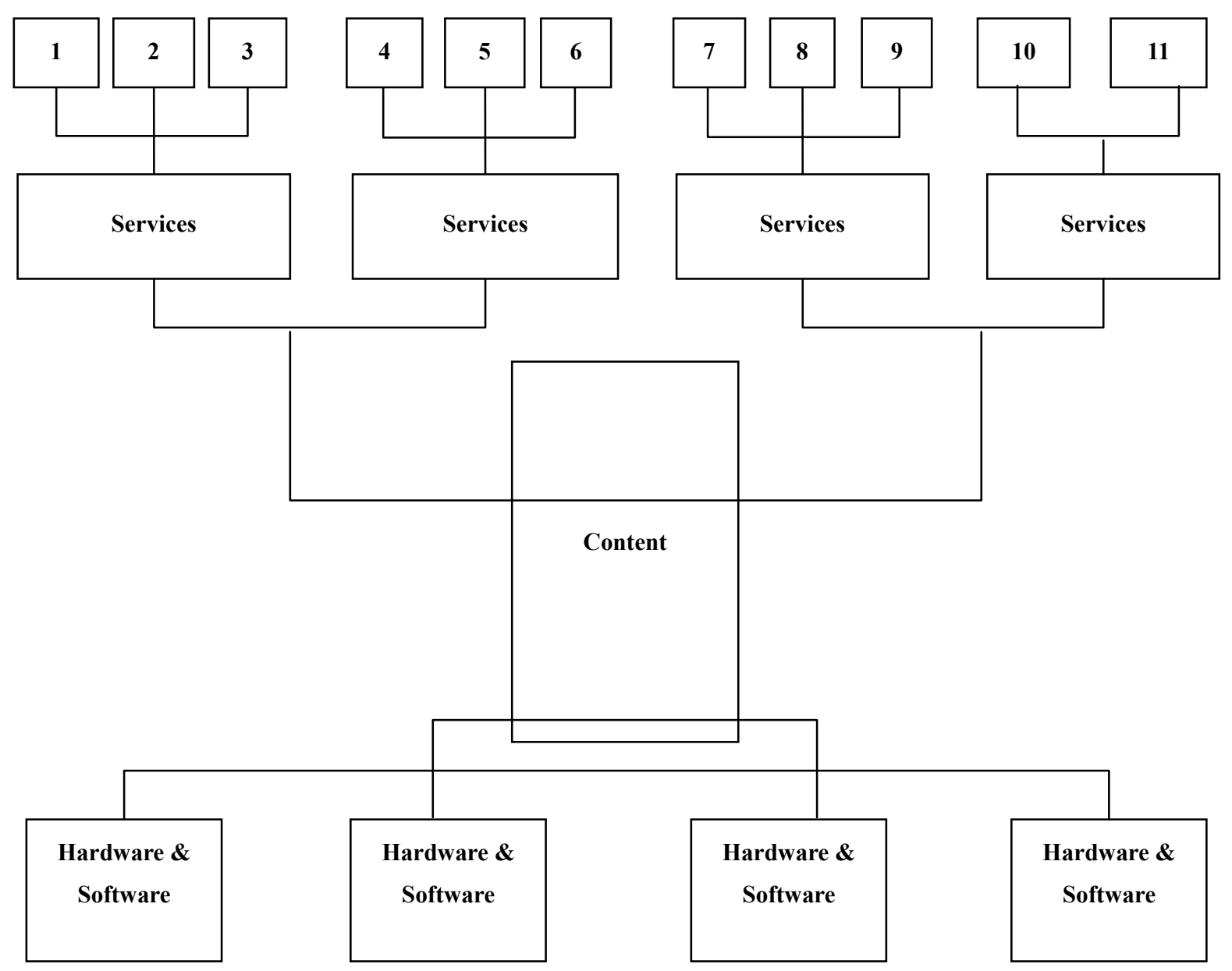

Figure 2. The core competency tree. Source: Adapted from Prahalad and Hamel (1990). 
Hamel and Prahalad (1993) identified three important benefits from achieving a core competency advantage. These were:

(1) core competencies provided access to a wide variety of markets;

(2) core competencies made a significant contribution to the benefits perceived by customers;

(3) core competencies were difficult for competitors to imitate.

During the period of conglomerate industrial growth (pre-1980s), firms would acquire companies in other industries and markets through the acquisition and ownership of physical and intangible assets. This would involve high capital costs and high gearing. However, a firm can now enter new markets and industries without making high risk acquisitions and taking possession of costly assets by leveraging its core competencies instead. The core competencies of the modern internet-based firms include the digital platform ecosystems that they have created and the vast amounts of customer data generated by these ecosystems. The "Big Five" internet based-firms have become information monopolies and this, rather than capital, has become the key resource requirement for market and industrial expansion. Companies can only process three things, namely: materials, information, and customers. Since modern service companies primarily process information (data) and customers, the "Big Five" information monopolies have a significant competitive advantage over traditional data-poor organizations.

The benefits perceived by customers are also enhanced. This use of big data has enabled the "Big Five" internet-based firms to capture, store, and process, in real time, vast amounts of customer data which is then used to target consumers with bespoke value propositions. These firms have set new standards in terms of speed, flexibility, and convenience, and they have raised customer expectations to new heights.

The third source of advantage is the inability of traditional firms to imitate the core competencies of the internet-based firms. The reasons for this are transparency, complexity, and scale. Being able to identify and understand core competencies is difficult because of their internal nature. However, when the core competencies are based on the collective learning of an entire ecosystem consisting of multiple-partner relationships then this involves huge levels of complexity. The sheer scale and size of the ecosystem also makes it impossible for traditional firms to respond to an ecosystem attack. Figure 3 illustrates how an ICT (information communications technology) ecosystem is configured.

The "Big Five" internet-based firms reside at Layer 3 in the overall ecosystem. It is this level of the ecosystem that generates the greatest economic rent whilst the infrastructure provision at Layer 1 and Layer 2 is comparatively commoditised. Layer 1 and 2 consist of the fixed line networks and the mobile networks of the telecommunications carriers and the infrastructure equipment providers. These networks are capital intensive and costly to maintain and upgrade. The internet-based firms therefore operate an asset-light business model by leasing capacity as and when required.

The new source of competitive advantage is the ability to evolve and grow a robust ecosystem that is open and guarantees high levels of biodiversity (multiple partners). Openness and biodiversity will enable the ecosystem to withstand external shocks such as new disruptive technologies and innovative business models, for example, if only one type of firm exists within a strategic group (McGhee \& Thomas, 1986) and there is only one business model, then the impact of a disruptive technology is likely to result in death or obsolescence. This was illustrated by the recent demise of Kodak and Polaroid due to digitisation. However, where multiple technologies, business models, and products exist (Table 2) involving multiple partners, a disruptive external 
shock is only likely to have a partial effect on the ecosystem by only eliminating specialist segments rather than the entire population. Openness to new firms, rather than barriers to entry, is also important since the new entrants enhance the resource base of the ecosystem and frequently provide complements to the core products and services being offered by the keystone firms (Iansiti \& Levien, 2004). This subsequently results in a portfolio of core competencies that can then be transformed into a portfolio of core businesses.

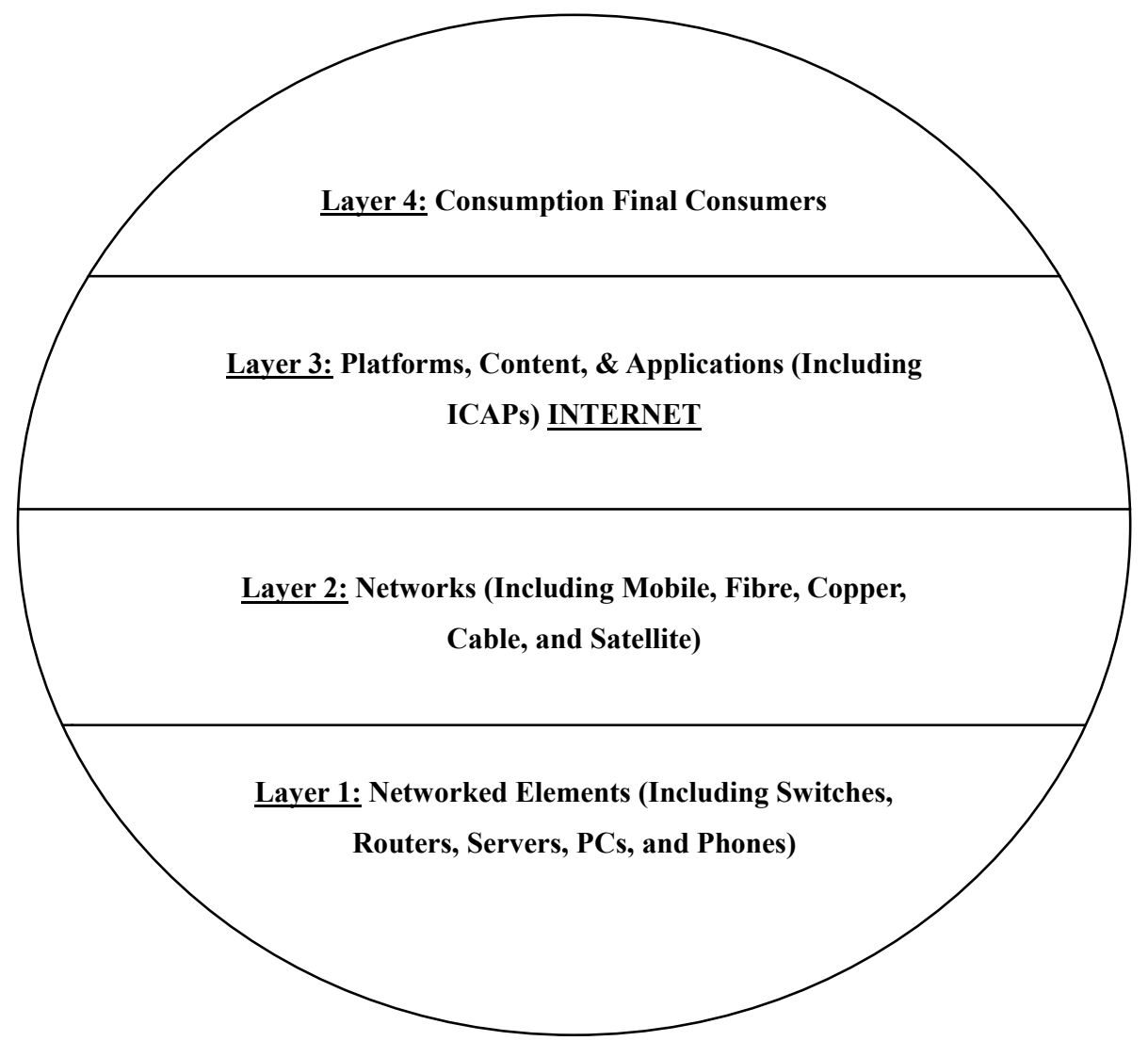

Figure 3. A simplified model of the new ICT ecosystem. Source: Fransman (2010).

\section{Methodology}

The research philosophy adopted for this paper is the critical paradigm. The methods used for the study involve secondary research only and the analysis of qualitative data that already exists in the public domain such as seminal journal articles by leading business academics.

It is the objective of this research to critically analyse existing strategic management theories through a process of deconstruction and then to undertake the reconstruction of alternative approaches. There are a number of existing theories relating to business ecosystems, but these pre-date the internet or focus purely on the digital aspects of the technology. The paper therefore analyses how these can be adapted and applied to the internet and the new age internet-based firms.

Furthermore, existing strategic management theories such as the classical planning approach and Porter's positioning school (1979) are not appropriate for the analysis of modern technology companies that compete across industries. The positioning school of strategy (Mintzberg, Ahlstrand, \& Lampel, 1998) has been heavily influenced by industrial organisation economics. This was perfectly acceptable during the industrial era but as 
large internet-based companies have now emerged to challenge the traditional firms and industries, a new approach is needed. The paper, therefore, uses strategic management theories from the resource-based school (Grant, 2008; Prahalad \& Hamel, 1990) and integrates them with the existing ecosystem concepts (Moore, 1996) to provide an explanation of how modern internet-based companies are changing business models and causing disruption in non-core traditional industries and markets. This is compared and contrasted with traditional Western conglomerate companies from the 1960s and 1970s. This means that the research is to some extent inductivist with new strategic perspectives being developed as an outcome.

\section{Findings}

\section{Impact of New Conglomerate Ecosystem Advantage on Markets and Industries}

The "Big Five" internet-based corporations are having a profound effect upon business model innovation in traditional markets and industries. A business model is the means by which a company creates value from its business. This can include key activities such as how it makes, distributes, prices, or advertises its products. A business model therefore provides a template for how a company chooses to compete in the marketplace.

The internet-based corporations are having a major impact upon traditional value creation activities through the disintermediation of supply chains. Where content is delivered digitally via the internet, it removes the need for a manufacturing and distribution capability. The physical printing of books, newspapers, and magazines, and the production of DVDs and CDs become obsolete. The warehousing and transport functions are removed as well as retail operations. The closure of Borders, Blockbuster, and HMV is a glaring manifestation of these recent trends. This has impacted heavily on publishing, media, and home entertainment and how they create value. Music streaming revenues increased by $40 \%$ globally in 2012 and was the fastest growing sector of the music industry (Retrieved from http://www.ifpi.org), whilst the streaming of digital movies outstripped DVD sales by one billion units in the same period. E-books also represented more than a quarter of total US book sales during the same year and Amazon currently sells more e-books than hard copies (Retrieved from http://www.publishers.org.uk)

Extensive disruption has also been caused by Apple and Google's move into mobile communications where the two companies hold dominant positions in hardware and software operating systems. As internet customers migrate to smart phones and tablets, this has resulted in a significant decline in personal computer sales which looks likely to continue. Global PC sales declined by $14 \%$ in the first quarter of 2013 and by $20 \%$ across Europe during the same period (Retrieved from http://www.gartner.com). Video game consoles have also declined (by $21 \%$ in 2012) as gamers move onto mobile internet-enabled devices (Retrieved from http://www.gartner.com). The software market has also been influenced by the activities of the internet-based companies leading to ecosystem rivalry among the different players. Google's decision to provide free downloadable software and Apple's development of the iPhone app (a simpler version of the software application) has altered the traditional value creation model of the industry. Packaged or boxed software is now being replaced by Cloud computing but the app is having an even more disruptive impact. More than 25 billion apps have been downloaded from Apple's app store, since it was started. These have undermined the traditional software pricing model since many of the apps are free or cost as little as $\$ 1$.

The business models of the advertising agencies and the brick and mortar retailers are also being heavily influenced. The "Big Five" are information-rich monopolies and gather customer data through a wide range of 
sources including search, e-commerce, social networks, app accounts, Cloud computing, and a multitude of other sources (Table 2). This has recently become known as big data. Big data is the collection, storage, and real time processing of large amounts of data to identify trends and patterns in behaviour (using algorithms). This capability enables the information-rich internet-based corporations to segment potential customers based on recognised patterns of behaviour and to monitor customer responses to any targeted marketing programmes. By generating large volumes of traffic, the internet-based companies not only attract advertising revenues from companies wanting to promote their products and services, but they are also able to track consumer behaviour. This enhances their bargaining power with the advertising agencies. The internet companies have also diverted advertising revenues away from traditional mass media such as newspapers, which was the fastest declining industry in the US until recently. In e-commerce, Amazon also uses big data algorithms to implement real price changes and monitor inventories. Traditional marketing activities such as primary market research, segmentation and pricing therefore become redundant and media buying will ultimately become a highly automated data-driven process (programmatic buying and selling).

Although Amazon still operates a traditional supply chain logistics model, business disruption is now evident in traditional brick and mortar retail stores due to showrooming. Consumers will visit retail stores to view products and then use mobile devices and apps to check the price of the goods online before making an internet purchase from another supplier such as Amazon. Many stores are now using "click and collect" and are considering pure showroom models where customers view the products before ordering from the store's in-house internet site.

Davenport et al. (2006) also emphasized the importance of multiple business models where a company needs to manage several business models simultaneously, for example, managing one business model that quickly becomes traditional is not adequate in high velocity fast moving technology markets. In order to remain competitive, companies require a portfolio of business models so that new business models replace the traditional ones (Figure 4).

The "Big Five" companies have retained their core traditional industry models but have significantly reinvented new experimental business models and are continuing to incubate further ideas (Figure 4).

Apple has continued to produce computers despite moving into mobile communications with its range of consumer devices including the iPod, iPhone, and iPad which are now accessible through the Apple Cloud. Amazon quickly moved from being an online bookstore to becoming a broad trading portal open to third party merchants. It has also developed its downloadable capability as well as moving into cloud computing and hardware devices such as e-readers and tablet computers. Google's strategy from the outset was to be more than simply another search engine which is still its core traditional business model. Due to the need to attract "traffic" onto its website (to sell more advertising), Google has incubated a broad range of new business models over the years including books, software browsers, e-mail, mobile phone software, Google Earth surveillance technologies, and social networking. Finally, Facebook is also more than simply a social networking site (its traditional business model). It has imitated many of the business models of the other four members of the "Big Five" and developed software apps and a hugely profitable advertising model. Microsoft has also retained its presence in personal computers but has expanded into enterprise software, Cloud computing, computer gaming, and mobile computing as well as trying to create a new ecosystem based on Windows 8 . 
So the "Big Five" not only have demonstrated multiple business-model capabilities, but also have shown a capacity for both sustainable (incremental) and disruptive (radical) innovation. These ecosystem companies have also demonstrated the strong innovation in all the three pathways of hardware and software, content, and services (Adomavicius et al., 2008).

This also demonstrates how the "Big Five" firms have been able to deploy strategies of stretch and leverage (Hamel \& Prahalad, 1993). The internet-based firms have created a chasm between their ambitions/aspirations and their resources and they have bridged the gap by leveraging a portfolio of ecosystem core competencies. During the conglomerate era, any core competencies that existed would have been the property of individual businesses and in most cases they wouldn't have been transferable due to the absence of any meaningful synergies.

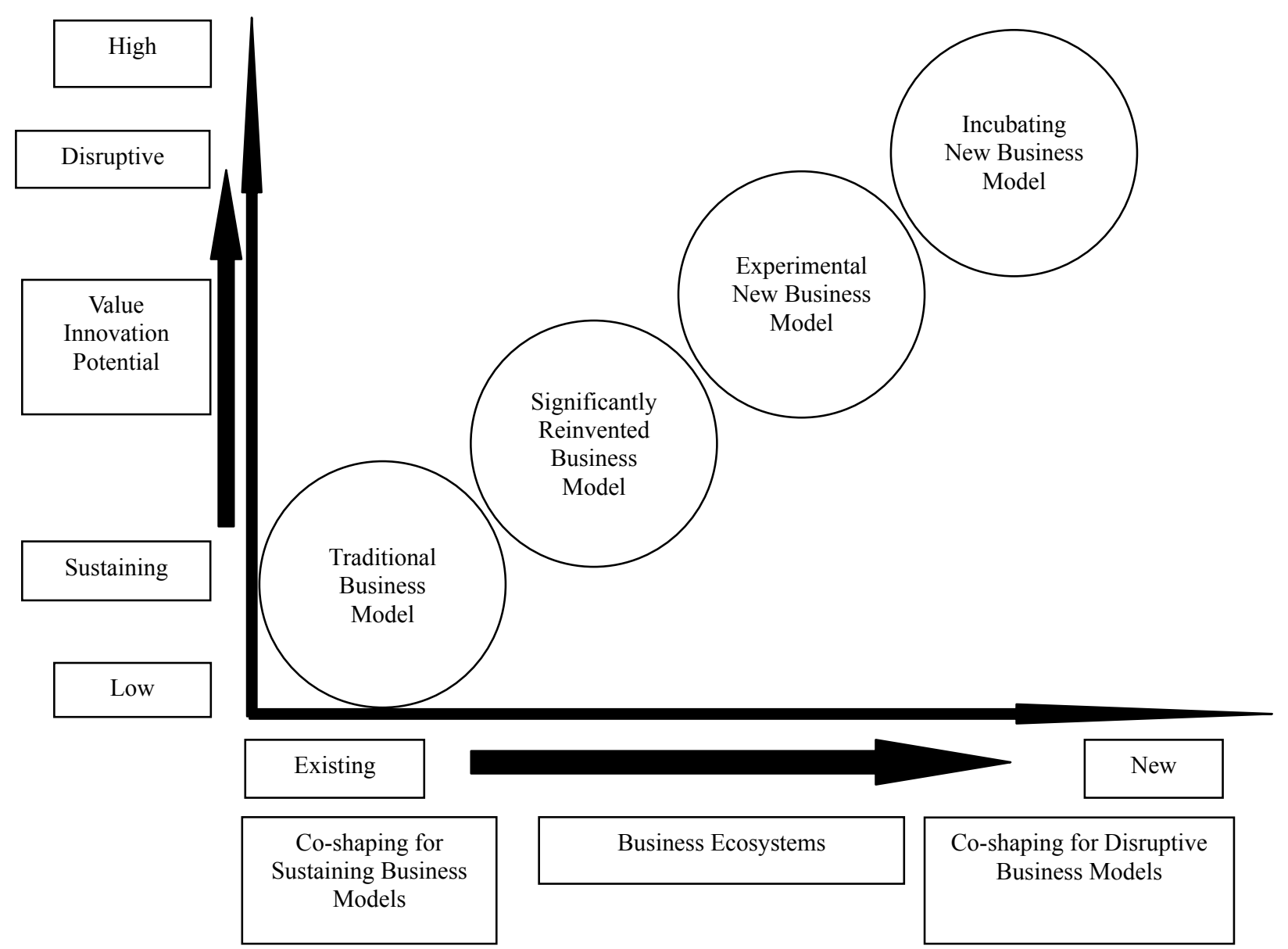

Figure 4. A portfolio of multiple business models. Source: Davenport, Leibold, and Voelpel (2006).

\section{Conclusions}

This paper has demonstrated how a new form of conglomerate organization has evolved that is capable of accessing multiple markets and industries by leveraging the core competencies provided by a technology platform and ecosystem advantage. This is in contrast to the Western industrial conglomerates of the 1960s and 1970s that expanded into a diverse range of sectors through aggressive mergers and acquisitions (M\&A) resulting 
in the ownership of a broad portfolio of physical and tangible assets that often destroyed value rather than providing synergies.

The paper also discussed how the "Big Five" have been able to establish a business model advantage over traditional firms because of their ability to operate comparatively asset-light structures. The internet-based firms can generate huge revenue streams from advertising and use the proceeds to offer free or subsidised products and services. The data-rich nature of their business models has also enabled them to target customers more effectively than non-internet based companies.

The ability of the incumbent firms in traditional markets and industries to reinvent their business models in the face of the internet-based ecosystem threat is very limited due to the sheer scale and complexity of their adversaries. The "Big Five" now represents a very powerful set of ecosystems consisting of an economic community of interacting organisations. These ecosystem companies have reinvented how products and services are delivered and consumed through the deployment of multiple business models. This will ultimately result in creative destruction for some firms and a radical restructuring of many industries and markets. This trail of disruption from internet-based firms is also likely to continue as people enter the era of machine-to-machine communication. This has been referred to as the internet-of-things (Ashton, 2009) where cars, households, and work places will soon become internet-enabled. This means that the power and reach of the new conglomerates are likely to increase rather than recede and "Big Data" will get even bigger.

\section{References}

Adomavicius, G., Bockstedt, J., Gupta, A., \& Kauffman, R. J. (2008). Making sense of technology trends in the information technology landscape: A design science approach. MIS Quarterly, 32(4), 779-809.

Ashton, K. (2009). That "internet of things" thing, in the real world things matter more than ideas. Retrieved from http://www.rfidjournal.com/articles/view?4986

Davenport, H., Leibold, M., \& Voelpel, S. (2006). Strategic management in the innovation economy. Erlangen: Wiley/Publicis.

Davis, G. F., Diekmann, K. A., \& Tinsley, C. H. (1994). The decline and fall of the conglomerate firm in the 1980s: The deinstitutionalization of an organizational form. American Sociological Review, 59(4), 547-570.

Eldredge, N., \& Gould, S. J. (1972). Punctuated equilibria: An alternative to phyletic gradualism. In T. J. M. Schopf (Ed.), Models in paleobiology (pp. 82-115). San Francisco: Freeman Cooper.

Fransman, M. (2010). The new ICT ecosystem: Implications for policy and regulation. New York: Cambridge University Press.

Gartner Technology Research. (2013). Gartner says worldwide PC shipments in the third quarter of 2013 declined 8.6 percent. Retrieved from: http://www.gartner.com.

Gawer, A. (2009). Platforms, markets and innovation (pp. 45-76). Northampton: Edward Elgar.

Gawer, A., \& Cusumano, M. (2002). Platform leadership: How Intel, Microsoft and Cisco drive industry innovation. Boston: Harvard Business School Press.

Grant, R. M. (2008). Contemporary strategy analysis (6th ed.). Oxford: Blackwell Publishing.

Hamel, G., \& Prahalad, C. K. (1993). Strategy as stretch and leverage. Harvard Business Review, 71(2), 75-84.

Iansiti, M., \& Levien, R. (2004). The keystone advantage: What the new dynamics of business ecosystems mean for strategy, innovation and sustainability. Boston: Harvard Business School Press.

International Federation of the Phonographic Industry. (2013). IFPI Digital Music Report 2013. Retrieved from http://www.ifpi.org

Johnston, M. (2000). Takeover: The new wall street warriors: The men, the money, the impact. Frederick: Beard Books.

McGhee, J., \& Thomas, H. (1986). Strategic groups: Theory, research, and taxonomy. Strategic Management Journal, 7(2), 141-160.

Mintzberg, H., Ahlstrand, B., \& Lampel, J. (1998). Strategy Safari: A guided tour through the wilds of strategic management. New York: Prentice Hall. 
Moore, J. F. (1996). The death of competition: Leadership \& strategy in the age of business ecosystems. New York: Harper Collins.

Porter, M. E. (1979). How competitive forces shape strategy. Harvard Business Review, 57(2), 137-145.

Porter, M. E. (2001). Strategy and the internet. Harvard Business Review, 79(3), 62-78.

Prahalad, C. K., \& Hamel, G. (1990). The core competence of the corporation. Harvard Business Review, 68(3), 79-91.

Publishers Association (2013). Amazon sells more e-books than printed titles. Retrieved from http://www.publishers.org.uk

Schumpeter, J. A. (1942). Can capitalism survive? Creative destruction and the future of the global economy. New York: Harper Perennial.

Slater, R. (1999). The titans of takeover. Frederick: Beard Books.

Sobel, R. (1999). The rise and fall of the conglomerate kings (2nd ed.). Frederick: Beard Books.

Walton, N. (2012). Four-closure: How Amazon, Apple, Facebook and Google are driving business model innovation. Chinese Business Review, 11(11), 981-988. 